\title{
The Chemical Evaluation of a Continuous-Smoking Inhalation Machine*
}

by

\author{
C. D. Briggs and J. McCready
}

Gallaher Limited, Research and Development Division, Belfast, Northern Ireland, United Kingdom

and

\author{
A. Schweizer \\ Battelle, Centre for Toxicology and Biosciences, Geneva, Switzerland
}

\section{INTRODUCTION}

The previous paper (1) described a design of inhalation smoking machine which is intended to present diluted smoke to 72 animals with a minimum delay.

The object of the present paper is to evaluate the machine in terms of smoke delivery, to compare the delivery with that of a reference analytical machine, and to account for any difference in delivery between machines. An appreciation of inhalation machine performance and its effects on smoke chemistry is necessary for the interpretation of biological results from animal exposures using this machine.

The paper will describe the methods and results obtained from an evaluation of the inhalation smoking machine in terms of $\mathrm{PMWNF}^{+}$, nicotine, carbon monoxide $(\mathrm{CO})$ and other smoke chemicals at various points in the machine

* Received: 28th September 1979 - accepted: 11th June 1980.

+ Particulate matter, water and nicotine free. (at the smoke pump, at the dilution chamber and at the animal ports), and will compare results with reference analytical data. Attempts will be made to account for any differences between the two machines, using a range of cigarette types at dilutions similar to those used in biological experiments.

\section{METHODS AND MATERIALS}

\section{Cigarettes}

The cigarettes used in this study are described in Table 1. Before smoking, the cigarettes were conditioned for at least 48 hours at $60 \%$ relative humidity and $21^{\circ} \mathrm{C}$, and were smoked under standard conditions, i.e. $35 \mathrm{ml}$ puff of 2 seconds duration, once per minute to a butt length of overwrap plus $3 \mathrm{~mm}$ (2). The cigarettes were not weight or pressure drop selected for this work.

Table 1. Clgarettes used in thls study.

\begin{tabular}{|c|c|c|c|c|c|c|c|c|c|}
\hline & \multicolumn{3}{|c|}{ Length (mm) } & \multirow{2}{*}{$\begin{array}{c}\text { Paper } \\
\text { type }\end{array}$} & \multirow{2}{*}{$\begin{array}{l}\text { Filter } \\
\text { type }\end{array}$} & \multirow{2}{*}{$\begin{array}{c}\text { Circum- } \\
\text { ference } \\
(\mathrm{mm})\end{array}$} & \multirow{2}{*}{$\begin{array}{c}\text { Weight } \\
\text { (mg) }\end{array}$} & \multirow{2}{*}{$\begin{array}{l}\text { Pressure } \\
\text { drop***} \\
\text { in daPa }\end{array}$} & \multirow{2}{*}{$\begin{array}{c}\text { Pressure } \\
\text { drop *** } \\
\text { in } \mathrm{mm} \mathrm{H}_{2} \mathrm{O} \\
\end{array}$} \\
\hline & overall & filler & filter & & & & & & \\
\hline $100 \%$ tobacco & 72 & 56 & 16 & low porosity & $\begin{array}{l}\text { dual, acetate/ } \\
\text { myria }\end{array}$ & 25.1 & 796 & 115 & 117 \\
\hline $\begin{array}{l}50 \% \text { tobacco: } \\
50 \% \text { Cytrel }\end{array}$ & 72 & 56 & 16 & low porosity & $\begin{array}{l}\text { dual, acetate/ } \\
\text { myria }\end{array}$ & 25.1 & 765 & 98 & 100 \\
\hline $100 \%$ Cytrel 0 & 72 & 56 & 16 & low porosity & $\begin{array}{l}\text { dual, acetate/ } \\
\text { myria }\end{array}$ & 25.1 & 782 & 97 & 99 \\
\hline $\begin{array}{l}50 \% \text { tobacco: } \\
50 \% \text { NSM } 14^{\star *}\end{array}$ & 72 & 56 & 16 & low porosity & $\begin{array}{l}\text { dual, acetate/ } \\
\text { myria }\end{array}$ & 25.1 & 771 & 105 & 107 \\
\hline $100 \%$ NSM 14 & 72 & 56 & 16 & low porosity & $\begin{array}{l}\text { dual, acetate/ } \\
\text { myria }\end{array}$ & 25.1 & 782 & 96 & 98 \\
\hline $\begin{array}{c}100 \% \text { tobacco, } \\
\text { ventllated }\end{array}$ & 72 & 55 & 17 & $\begin{array}{l}\text { medium } \\
\text { porosity }\end{array}$ & $\begin{array}{c}\text { dual, acetate/ } \\
\text { myria-carbon } \\
\text { (ventilated) }\end{array}$ & 25.1 & 760 & 127 & 130 \\
\hline
\end{tabular}

\footnotetext{
- Cytrel• is a registered trade mark of Celanese Corporation. 
Flgure 1. Schematic layout of Inhalation machine.

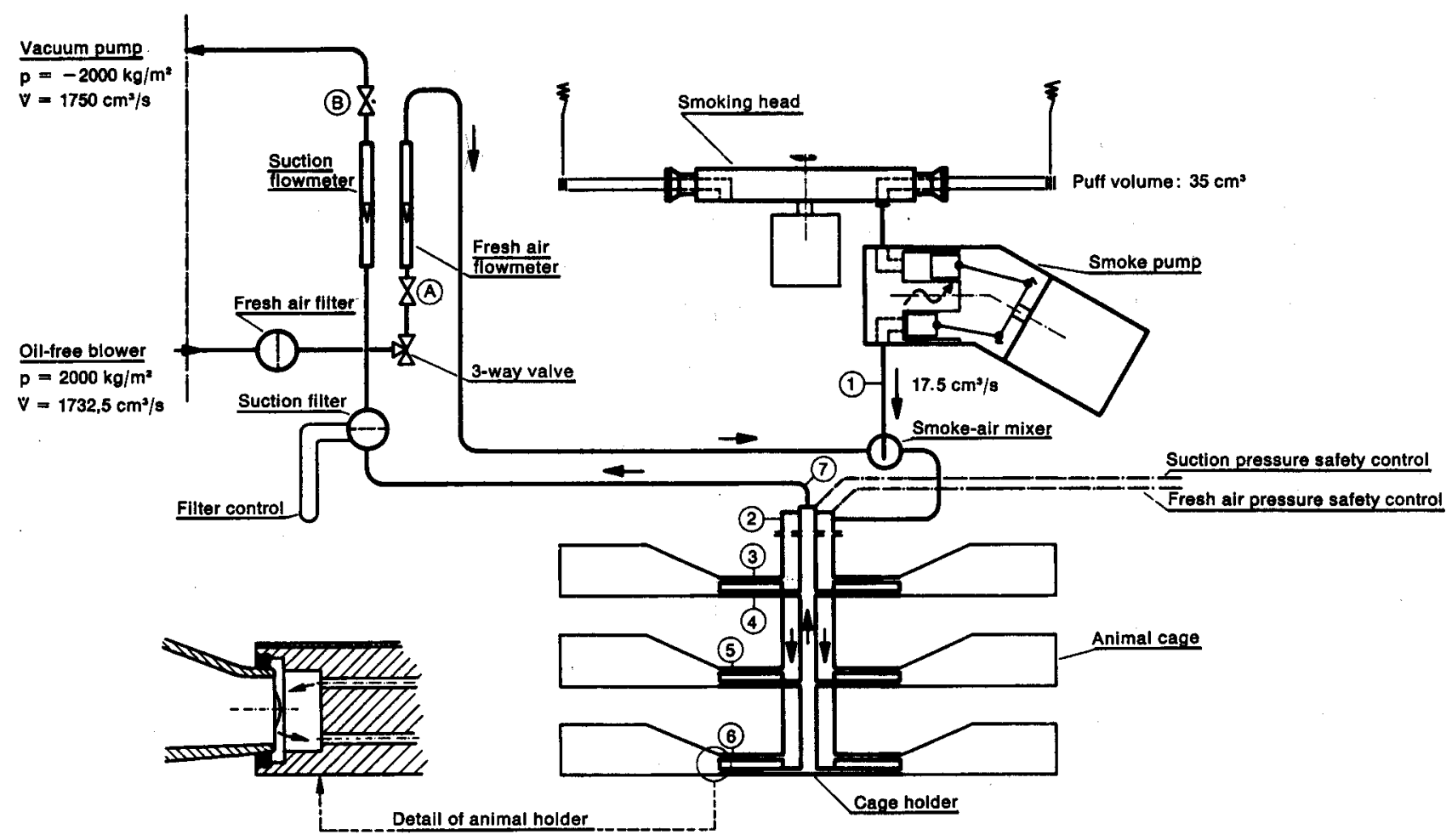

Table 2. Comparison for various cigarettes of undlluted smoke deliveries from inhalation machine with analytical data.

\begin{tabular}{|c|c|c|c|c|c|}
\hline Cigarette & Smoking machine & $\begin{array}{c}\text { PMWNF * } \\
\text { (mg/cigarette) }\end{array}$ & $\begin{array}{c}\text { Nicotine } \\
\text { (mg/cigarette) }\end{array}$ & $\begin{array}{c}\text { CO } \\
\text { (mg/cigarette })\end{array}$ & Puff number \\
\hline \multirow{3}{*}{$100 \%$ tobacco } & Inhalation & $16.3 \pm 0.2$ & $1.18 \pm 0.03$ & $16.2 \pm 0.3$ & $9.1 \pm 0.2$ \\
\hline & Analytical & $19.7 \pm 0.9$ & $1.35 \pm 0.03$ & $17.2 \pm 0.7$ & $10.2 \pm 0.3$ \\
\hline & Ratio inhalation : analytical & $0.83 \pm 0.03$ & $0.87 \pm 0.02$ & $0.94 \pm 0.03$ & $0.89 \pm 0.02$ \\
\hline \multirow{3}{*}{$\begin{array}{c}50 \% \text { tobacco: } \\
50 \% \text { Cytrel }\end{array}$} & Inhalation & $8.5 \pm 0.9$ & $0.32 \pm 0.03$ & $10.9 \pm 0.5$ & $6.2 \pm 0.1$ \\
\hline & Analytical & $10.9 \pm 0.3$ & $0.51 \pm 0.02$ & $12.5 \pm 0.6$ & $7.1 \pm 0.1$ \\
\hline & Ratio inhalation : analytical & $0.78 \pm 0.07$ & $0.63 \pm 0.05$ & $0.88 \pm 0.04$ & $0.87 \pm 0.01$ \\
\hline \multirow{3}{*}{$100 \%$ Cytrel } & Inhalation & $3.1 \pm 0.1$ & 0 & $4.5 \pm 0.1$ & $5.0 \pm 0.0$ \\
\hline & Analytical & $4.1 \pm 0.2$ & 0 & $5.4 \pm 0.2$ & $5.6 \pm 0.1$ \\
\hline & Ratio inhalation : analytical & $0.76 \pm 0.03$ & - & $0.85 \pm 0.02$ & $0.89 \pm 0.01$ \\
\hline \multirow{3}{*}{$\begin{array}{l}50 \% \text { tobacco : } \\
50 \% \text { NSM } 14\end{array}$} & Inhalation & $10.2 \pm 0.7$ & $0.39 \pm 0.02$ & $13.4 \pm 0.3$ & $8.1 \pm 0.2$ \\
\hline & Analytical & $12.7 \pm 0.4$ & $0.56 \pm 0.02$ & $15.8 \pm 0.9$ & $9.2 \pm 0.1$ \\
\hline & Ratio inhalation : analytical & $0.80 \pm 0.05$ & $0.70 \pm 0.03$ & $0.85 \pm 0.04$ & $0.88 \pm 0.02$ \\
\hline \multirow{3}{*}{$100 \%$ NSM 14} & Inhalation & $3.8 \pm 0.5$ & 0 & $11.5 \pm 0.4$ & $9.3 \pm 0.4$ \\
\hline & Analytical & $5.6 \pm 0.6$ & 0 & $11.4 \pm 1.2$ & $9.9 \pm 0.4$ \\
\hline & Ratio inhalation : analytical & $0.68 \pm 0.09$ & - & $1.02 \pm 0.08$ & $0.94 \pm 0.04$ \\
\hline \multirow{3}{*}{$\begin{array}{c}100 \% \text { tobacco, } \\
\text { ventilated }\end{array}$} & Inhalation & $8.1 \pm 0.8$ & $0.49 \pm 0.03$ & $10.0 \pm 0.5$ & $8.4 \pm 0.1$ \\
\hline & Analytical & $9.2 \pm 0.4$ & $0.70 \pm 0.10$ & $11.5 \pm 1.0$ & $9.3 \pm 0.2$ \\
\hline & Ratio inhalation : analytical & $0.88 \pm 0.07$ & $0.72 \pm 0.08$ & $0.88 \pm 0.06$ & $0.90 \pm 0.02$ \\
\hline
\end{tabular}

\footnotetext{
- Particulate matter, water and nicotine free.
} 


\section{Analytical Smoke Chemistry}

PMWNF, nicotine and $\mathrm{CO}$ were analysed using a Filtrona 300 twenty-channel piston smoking machine fitted with an automated $\mathrm{CO}$ collection and analysis unit (ATCOM 20) (3). Wet particulate matter (PM) was determined gravimetrically, nicotine by a steam distillation and spectrophotometric procedure, and water by gas chromatography (2). Carbon monoxide, after collection of vapour phase in the plastic bags of the ATCOM 20, was analysed by a non-dispersive infrared (NDIR) technique (2).

Hydrogen cyanide, total volatile aldehydes and steam volatile phenols were analysed using a 6-channel constant flow smoking machine using procedures described in (2). Formaldehyde was analysed on the same mactine using a spectrophotometric procedure described by $S$ pincer and Chard (4).

\section{Inbalation Machine Smoke Chemistry}

The details of the inhalation smoking machine are described elsewhere (1). The inhalation smoking machine was allowed to run for $\mathbf{2}$ hours prior to any experimentation; previous tests had established that puff volume was constant both with and without cigarettes after this initial warm up period. To sample and collect smoke immediately behind the pump (i.e. undiluted smoke), the dilution chamber was disconnected from the pump and the smoke was diverted into the appropriate trapping system for the analysis under consideration. Traps and analytical procedures were similar to those used in the analytical smoking procedures. Puffs of smoke taken into the traps were equivalent to those used in the analy tical procedures; puff numbers on the turntable were randomized to eliminate any possibility of biased data. Flow rates were monitored throughout the analyses using rotameters calibrated against a wet gas meter.

Sampling of the diluted smoke at the distribution head and the upper, middle and lower animal levels was achieved by connecting a vacuum pump via a $T$ piece at the appropriate position and pumping from these points through the appropriate trapping system. Diluted smoke was sampled over a 30-minute period; procedures were similar to those used in the analytical smoking.

In all cases, for analytical and inhalation smoking at each sampling point, at least 5 analyses were performed and results quoted are the means of these individual analyses. In the tables of results means and associated $95 \%$ confidence limits are given, unless otherwise stated. In comparisons of inhalation and analytical smoking machine data, the $95 \%$ confidence limit of the yield ratio inhalation : analytical madhine is given by the equations:

$$
\begin{aligned}
& \text { variance of the ratio }\left(\frac{\bar{x}_{1}}{\bar{x}_{3}}\right)= \\
& =\left\{\text { variance }\left(\bar{x}_{1}\right)+\left(\frac{\bar{x}_{1}}{\bar{x}_{2}}\right)^{2} \cdot \text { variance }\left(\bar{x}_{2}\right)\right\} \frac{1}{\left(\bar{x}_{2}\right)^{2}}
\end{aligned}
$$

and

$$
\begin{aligned}
& 95 \% \text { confidence limit of ratio }\left(\frac{\bar{x}_{1}}{\bar{x}_{2}}\right)= \\
& =t \cdot \sqrt{\text { variance }\left(\frac{\bar{x}_{1}}{\bar{x}_{2}}\right)},
\end{aligned}
$$

where

$\vec{x}_{1}$ is the mean inhalation machine smoke yield,

$\overline{\mathbf{x}}_{2}$ is the mean analytical machine smoke yield,

$t$ is the value from Student's $t$ tables.

\section{Estimation of Deposition}

One of the main differences between the inhalation and analytical smoking madhines is that in the former the pump is situated between the cigarettes and the trapping system (for sampling undiluted smoke). Deposition of smoke in the pump (or in the pipework behind the pump if sampling diluted smoke) is a possibility and so a method was developed to estimate this deposition level using nonvolatile whole smoke condensate (NVWSC) (2). Starting with a clean machine (i.e. all pipework washed out with acetone) smoking was carried out in the usual manner, collecting the PM on a Cambridge filter pad at the appropriate sampling point. After smoking the specified number of cigarettes, the pump and pipework were washed with acetone and an aliquot was quantitatively assayed for nicotine. The remainder was rotary evaporated to constant weight at $40^{\circ} \mathrm{C}$ and $133 \mathrm{daPa}(10 \mathrm{~mm}$ $\mathrm{Hg}$ ) to give a quantitative NVWSC yield (2). From correlations between NVWSC and PMWNF previously established for each product on test, the PMWNF equivalent deposited in the inhalation machine could be calculated. For example, for a $100 \%$ tobacco cigarette PMWNF was $19.7 \mathrm{mg} /$ cigarette and NVWSC $15.7 \mathrm{mg} /$ cigarette, giving a relationship of PMWNF (mg/cigarette) $=$ NVWSC $(\mathrm{mg} /$ cigarette $) \times 1.255$. The deposition calculated in this way can be added to that collected on the pad in order to estimate the total PMWNF or nicotine delivery by the cigarette.

\section{RESULTS AND DISCUSSION}

\section{Comparison of Undiluted Smoke Delivery with Analytical Data}

\section{PMWNF, Nicotine, CO}

The delivery of smoke immediately behind the pump, i.e. position 1 (Figure 1), was compared to that delivered by a Filtrona 300 analytical smoking machine. Table 2 summarises data for a series of cigarette model products and shows that the inhalation machine consistently delivered less smoke than the analytical machine, although deliveries of $\mathrm{CO}$ were not so greatly reduced as were those of PMWNF and nicotine. Puff numbers were also consistently lower in the inhalation machine.

To try to explain the differences between the observed smoke deliveries from the two madhines, the following 


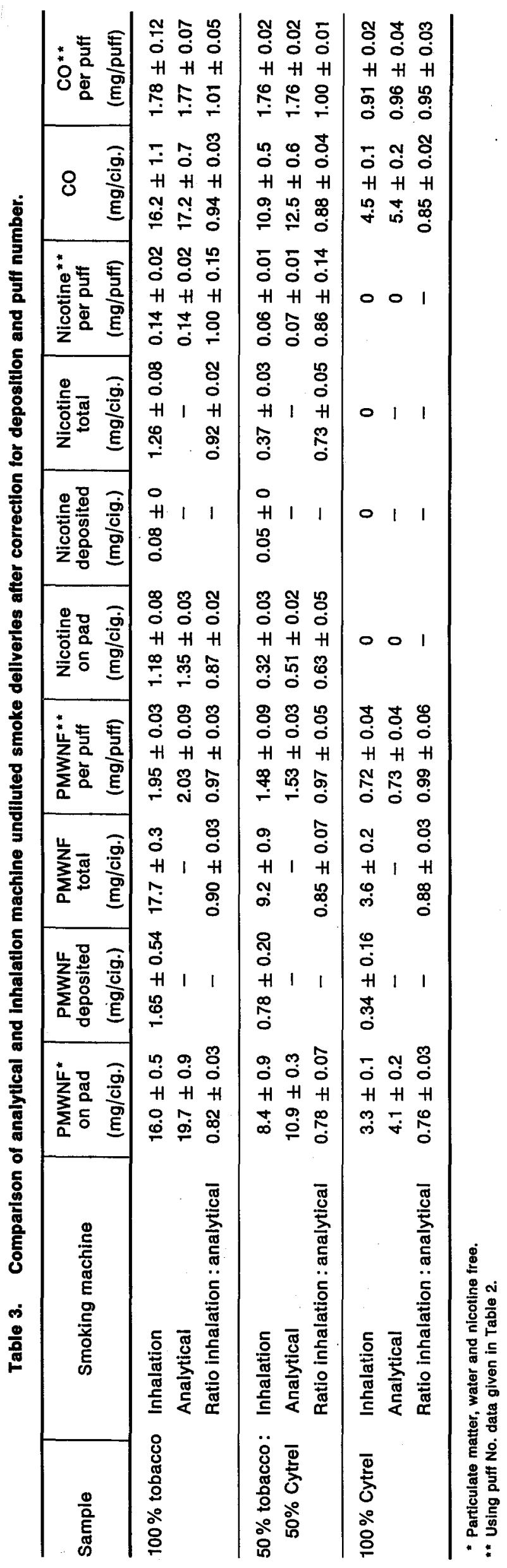


possibilities were investigated (bearing in mind that puff volume, cigarette conditioning, puff duration, puff interval and butt length were identical in the two machines):

a) Deposition of PM inside the pump: This can happen in the inhalation machine as the pump is sited between the cigarettes and the Cambridge filter pad. The observation that $\mathrm{CO}$ differences between the two machines were small compared to PMWNF and nicotine differences suggests that particulates could be deposited inside the pump. To evaluate this, the pump and pathway were washed with acetone after smoking and NVWSC yield (and nicotine) measured on the washings as described previously. Such determinations were made on a range of products and data are summarised in Table 3 , in which corrected yields are given after allowance for deposition. If the data from inhalation and analytical machines are then corrected for the difference in puff number, by quoting an average yield per puff, analytical and inhalation data compare quite favourably.

b) Free burning time: In the inhalation machine, cigarettes are on a rotating turntable whereas in the analytical machine they are stationary, possibly introducing differences in free burning. Although a given cigarette gave identical free burning times without puffing on both machines, differences were observed when a puffing cycle was introduced. Figure 2 illustrates the differences between inter-puff free burning and puffing paper regressions for the two machines. The inhalation machine gave much greater regressions between puffs, and slightly greater regressions during puffs, than the analytical machine using a $100 \%$ tobacco cigarette. The difference in inter-puff free burning could account for the observed puff number difference between the two machines, possibly through a difference in cone shapes immediately after puffing in the two different profiles (bell-shaped v. square wave).

c) Restricted $v$. unrestricted smoking*: The analytical smoking machine uses restricted smoking, the inhalation machine unrestricted. This could account for the differences in PM delivery in addition to the paper regressions discussed above. Using a comparable rotary turntable which gave restricted smoking, it was possible to compare smoke

Table 4. Comparison of restricted and unrestricted smokIng using $100 \%$ tobacco clgarettes on rotary machinery.

\begin{tabular}{l|c|c|c}
\hline $\begin{array}{l}\text { Smoking } \\
\text { machine }\end{array}$ & $\begin{array}{c}\text { PMWNF* } \\
\text { (mg/cigarette) }\end{array}$ & $\begin{array}{c}\text { Nicotine } \\
\text { (mg/cigarette) }\end{array}$ & $\begin{array}{c}\text { Puff } \\
\text { number }\end{array}$ \\
\hline Restricted & $19.2 \pm 1.0$ & $1.36 \pm 0.08$ & $9.6 \pm 0.4$ \\
Unrestricted & $18.7 \pm 0.9$ & $1.29 \pm 0.05$ & $9.2 \pm 0.3$ \\
\hline
\end{tabular}

- Particulate matter, water and nicotine free.

deliveries directly with the inhalation machine. Results (Table 4) indicate that the style of smoking does not contribute to the observed differences in smoke delivery for the products used in this study.

\footnotetext{
* Restricted and unrestricted smoking are, respectively, the conditions that exist when the butt end of the cigarette is closed and open to the atmosphere between successive puffs.
}

Figure 2. Comparlson of paper regressions during puffing and during the Inter-puff tree burning Interval for the Inhalation and analytical smoking machines $(100 \%$ tobacco

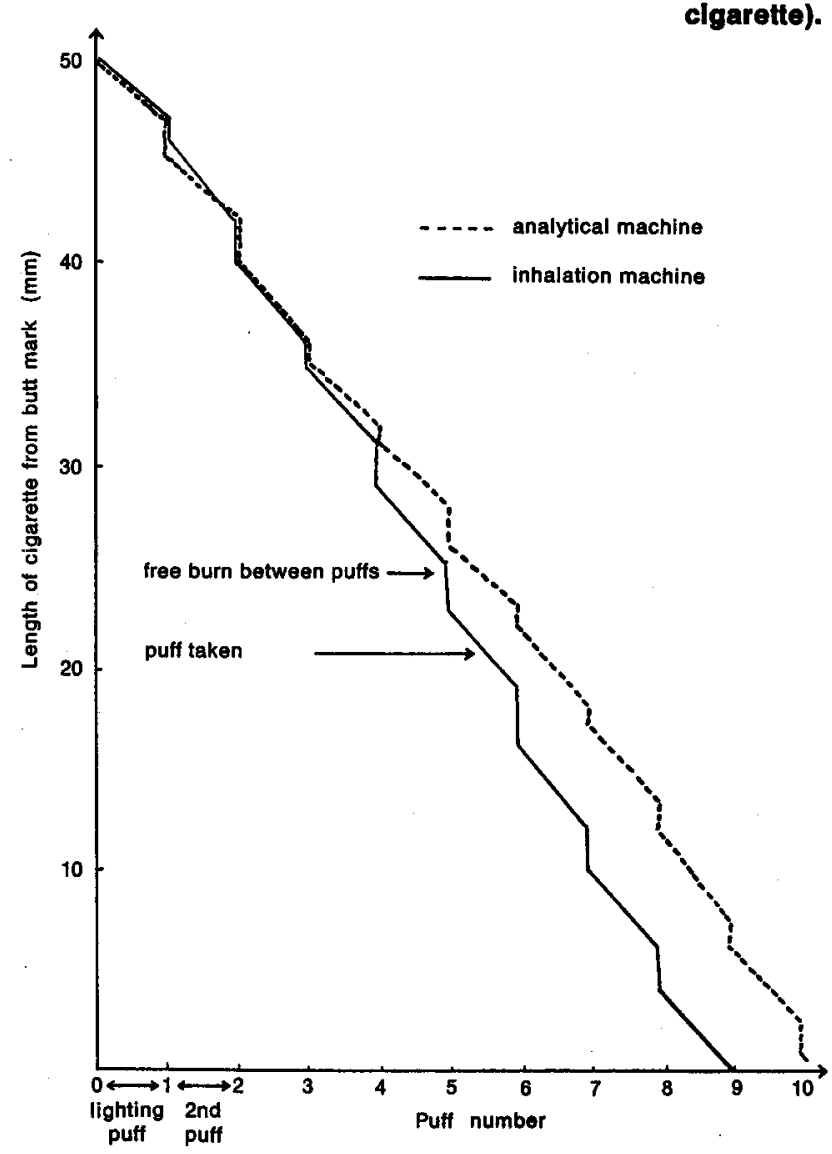

d) Puff profile effects: The analytical machine has a bell-shaped profile whereas the inhalation machine has a square wave. It was not possible to investigate the effect of this parameter: Seebofer and Scbulz (5) claimed that no differences were observed on filter cigarettes for these two puff profiles.

e) Effect of neighbouring cigarettes during smoking: On the inhalation machine, the axes of two adjacent cigarettes on the turntable are $23-33 \mathrm{~mm}$ apart, as opposed to the analytical machine, where they are $65 \mathrm{~mm}$ apart. Each cigarette on the inhalation machine could heat its neighbours by irradiation. To clarify the effect of this, the PMWNF, nicotine and CO yields were recorded for thirty $100 \%$ tobacco cigarettes smoked in rotation, 5 cigarettes smoked in rotation on adjacent ports and 5 cigarettes smoked consecutively in one single port, on the inhalation smoker. Results (Table 5) show that any irradiation effects, if present, do not adversely affect smoke yields.

f) Cigarette lighting: The inhalation machine uses flame ignition, whereas the analytical machine uses electrical ignition. The lighting puff regression was identical in both 


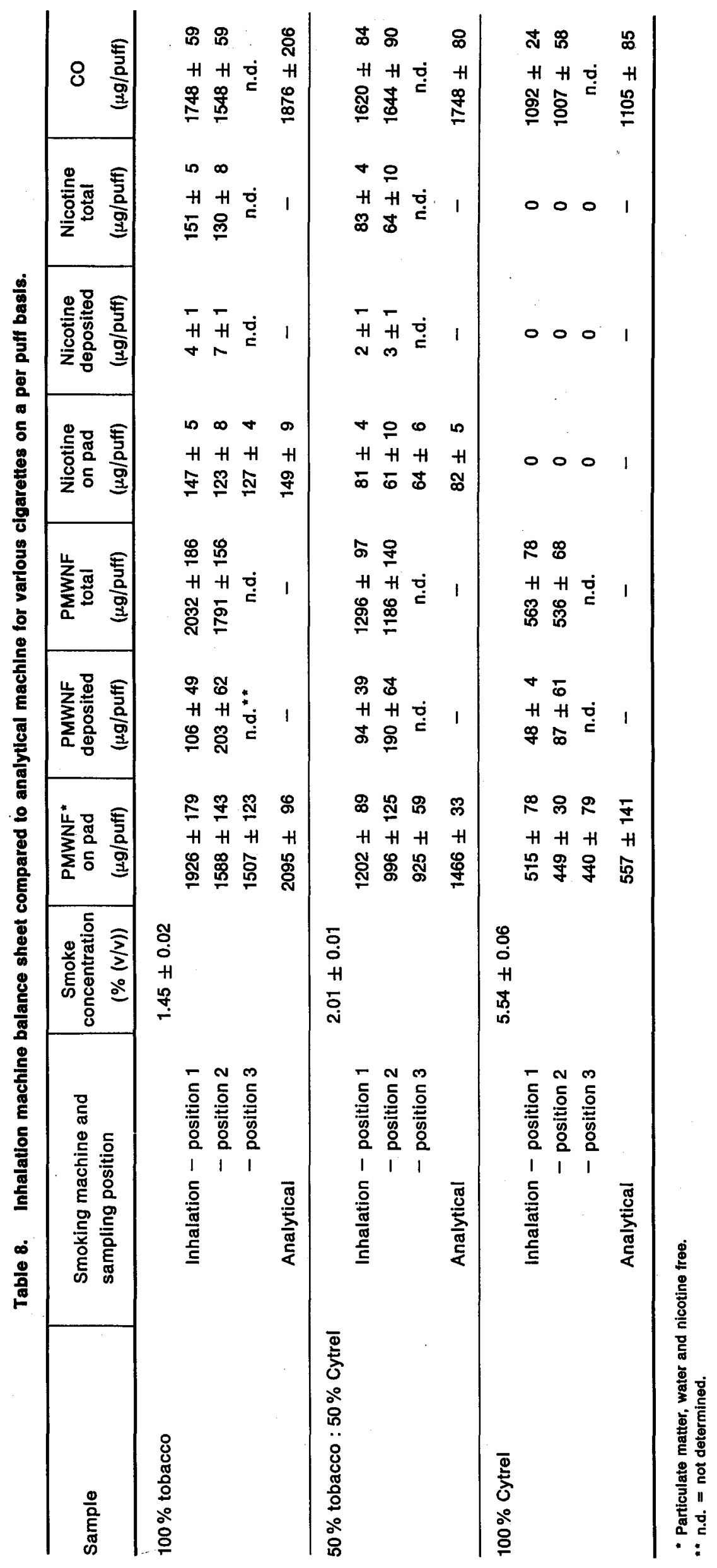


Table 5. The effect of nelghbouring clgarettes on each other during smoking - Inhalation machine (100\% tobacco clgarettes).

\begin{tabular}{l|c|c|c|c}
\hline Experiment & $\begin{array}{c}\text { PMWNF* } \\
(\mathrm{mg} / \text { cig. })\end{array}$ & $\begin{array}{c}\text { Nicotine } \\
(\mathrm{mg} / \mathrm{cig} .)\end{array}$ & $\begin{array}{c}\mathrm{CO} \\
(\mathrm{mg} / \mathrm{cig} .)\end{array}$ & $\begin{array}{c}\text { Puff } \\
\text { number }\end{array}$ \\
\hline $\begin{array}{l}30 \text { cigarettes in } \\
\text { rotation }\end{array}$ & 15.3 & 1.12 & 16.0 & 9.0 \\
$\begin{array}{l}5 \text { cigarettes in } \\
\text { rotation (adjacent } \\
\text { ports) }\end{array}$ & 15.7 & 1.14 & 16.2 & 9.0 \\
$\begin{array}{l}5 \text { cigarettes on } \\
\text { a single port }\end{array}$ & 15.1 & 1.12 & 15.9 & 9.0 \\
\hline
\end{tabular}

- Particulate matter, water and nicotine free.

machines, and was generally thought unlikely to contribute to the observed differences.

It would appear, therefore, that the losses incurred at the sampling position 1 , immediately behind the pump, are due to two main causes: (a) deposition within the pump and (b) differences in puff number.

\section{Other Smoke Chemicals}

Having determined smoke quantity at sampling position 1 and smoke quality using $\mathrm{CO}$ and nicotine, it was decided to compare deliveries of certain key chemicals in the smoke. Thus hydrogen cyanide, total volatile aldehydes, steam volatile phenols and formaldehyde were measured in the undiluted smoke. Results (Table 6) suggest that there is little difference between the two smoking machines in the delivery of these chemicals.

\section{Comparison of Diluted Smoke Delivery with Analytical Data}

For this aspect of the work, four sampling positions were available (Figure 1): at the top of the animal trays (position 2), and at each of the three trays (positions $3,4,5$ ). A preliminary investigation using a 50\% tobacco: $50 \%$ Cytrel cigarette at a smoke concentration of $2.0 \%(\mathrm{v} / \mathrm{v})$ was undertaken to establish if any differences existed between the three animal tray levels. Results (Table 7)
Table 7. Comparison of smoke delivery data at the three animal port levels (positions $3,4,5$ ) from $50 \%$ tobacco : $50 \%$ Cytrel cigarette at $2 \%(v / v)$ smoke concentration.

\begin{tabular}{l|r|c|c}
\cline { 2 - 5 } & $\begin{array}{c}\text { Position 3 } \\
\text { (upper } \\
\text { level) }\end{array}$ & $\begin{array}{c}\text { Position 4 } \\
\text { (middle } \\
\text { level) }\end{array}$ & \multicolumn{1}{c}{$\begin{array}{c}\text { Position 5 } \\
\text { (lower } \\
\text { level) }\end{array}$} \\
\hline PMWNF $^{*}(\mu \mathrm{g} /$ puff) & $924 \pm 142$ & $933 \pm 146$ & $919 \pm 125$ \\
Nicotine ( $\mu \mathrm{g} /$ puff) & $64 \pm 12$ & $64 \pm 33$ & $64 \pm 14$ \\
\hline
\end{tabular}

- Partlculate matter, water and nicotine free.

show that there were no statistically significant differences between the three levels.

Positions 1, 2, 3 were sampled using three cigarette types at smoke concentrations typical of those used in animal inhalation experiments. In addition to measuring PMWNF, nicotine and $\mathrm{CO}$ at the three positions, deposition was measured up to positions 1 and 2. Recognising that puff number is a major difference between the inhalation and analytical machines, all data are expressed as average yields per puff. Actual deliveries and comparisons with analytical machine data are given in Table 8; ratios of inhalation and analytical machine data are shown in Table 9.

In actual deliveries on a per puff basis, the inhalation machine delivers slightly less smoke to position 1 than the analytical data would indicate, the difference being wholly accountable for by deposition. There are further losses in actual delivery to position 2 and again to position 3, particularly in PMWNF, as indicated in Table 8, and after accounting for deposition there still appear to be losses. Carbon monoxide deliveries are slightly lower at positions 2 and 3 and these could suggest some evidence of leakage. For example, the total recoveries for PMWNF, nicotine and $\mathrm{CO}$ for the $100 \%$ tobacco product at position 2 are about $85 \%$. There is also evidence of PMWNF's selectively depositing $(11 \%-16 \%)$ compared to nicotine $(5 \%)$, indicating that nicotine may be transferred in part to the vapour phase.

Some studies were made on hydrogen cyanide and total volatile aldehyde deliveries to the 1 st level of the animal trays - position 3 - using 100\% tobacco cigarettes at $1.45 \%(\mathrm{v} / \mathrm{v})$ smoke concentration. Table 10 indicates an average recovery of $85 \%$ of these chemicals when calcu-

Table 6. Comparison of smoke chemistry: undiluted smoke from Inhalation machine v. analytical machine.

\begin{tabular}{|c|c|c|c|c|c|}
\hline Samples & Smoking machine & $\begin{array}{c}\mathrm{HCN} \\
(\mu \mathrm{g} / \text { cigarette) }\end{array}$ & $\begin{array}{c}\text { Aldehydes } \\
\text { (mg/cigarette) }\end{array}$ & $\begin{array}{c}\text { Formaldehyde } \\
(\mu \mathrm{g} / \text { cigarette) }\end{array}$ & $\begin{array}{c}\text { Phenols } \\
(\mu g / \text { cigarette })\end{array}$ \\
\hline \multirow{3}{*}{$100 \%$ tobacco } & Inhalation & $297 \pm 14$ & $1.9 \pm 0.1$ & $82 \pm 2$ & $87 \pm 3$ \\
\hline & Analytical & $330 \pm 14$ & $2.5 \pm 0.1$ & $77 \pm 3$ & $90 \pm 2$ \\
\hline & Ratio inhalation : analytical & $0.90 \pm 0.06$ & $0.76 \pm 0.04$ & $1.06 \pm 0.04$ & $0.97 \pm 0.04$ \\
\hline \multirow{3}{*}{$\begin{array}{c}50 \% \text { tobacco: } \\
50 \% \text { Cytrel }\end{array}$} & Inhalation & $136 \pm 12$ & $1.2 \pm 0.1$ & $62 \pm 5$ & $33 \pm 3$ \\
\hline & Analytical & $144 \pm 11$ & $1.3 \pm 0.1$ & $53 \pm 3$ & $32 \pm 7$ \\
\hline & Ratio inhalation : analytical & $0.94 \pm 0.10$ & $0.92 \pm 0.11$ & $1.13 \pm 0.11$ & $1.03 \pm 0.07$ \\
\hline \multirow{3}{*}{$100 \%$ Cytrel } & Inhalation & $7 \pm 1$ & $0.2 \pm 0.1$ & $10 \pm 3$ & $15 \pm 4$ \\
\hline & Analytical & $5 \pm 1$ & $0.5 \pm 0.1$ & $12 \pm 1$ & $17 \pm 3$ \\
\hline & Ratio inhalation : analytical & $1.40 \pm 0.30$ & $0.40 \pm 0.05$ & $0.83 \pm 0.25$ & $0.88 \pm 0.25$ \\
\hline
\end{tabular}


Table 9. Ratio of Inhalation machine ylelds compared to analytical machine for varlous clgarettes on a per puff basis.

\begin{tabular}{|c|c|c|c|c|c|c|c|}
\hline Sample & $\begin{array}{l}\text { Smoking machine and } \\
\text { sampling position }\end{array}$ & $\begin{array}{c}\text { Smoke } \\
\text { concen- } \\
\text { tration } \\
(\%(v / v))\end{array}$ & $\begin{array}{l}\text { PMWNF* } \\
\text { on pad }\end{array}$ & $\begin{array}{c}\text { PMWNF ** } \\
\text { total }\end{array}$ & $\begin{array}{l}\text { Nicotine } \\
\text { on pad }\end{array}$ & $\begin{array}{l}\text { Nicotine } \\
\text { total }\end{array}$ & co \\
\hline $100 \%$ tobacco & $\begin{array}{l}\text { inhalation (position } 1 \text { ): } \\
\text { analytical } \\
\text { inhalation (position 2): } \\
\text { analytical } \\
\text { inhalation (position } 3 \text { ): } \\
\text { analytical }\end{array}$ & $1.45 \pm 0.02$ & $\begin{array}{c}0.92 \pm 0.07 \\
0.76 \pm 0.06 \\
\quad \cdot \\
0.72 \pm 0.05\end{array}$ & $\begin{array}{c}0.97 \pm 0.07 \\
0.85 \pm 0.06 \\
-\end{array}$ & $\begin{array}{l}0.99 \pm 0.05 \\
0.83 \pm 0.06 \\
0.85 \pm 0.04\end{array}$ & $\begin{array}{c}1.01 \pm 0.05 \\
0.87 \pm 0.06 \\
-\end{array}$ & $\begin{array}{c}0.93 \pm 0.08 \\
0.83 \pm 0.07 \\
-\end{array}$ \\
\hline $\begin{array}{c}50 \% \text { tobacco : } \\
50 \% \text { Cytrel }\end{array}$ & $\begin{array}{l}\text { Inhalation (position 1): } \\
\text { analytical } \\
\text { inhalation (position 2): } \\
\text { analytical } \\
\text { inhalation (position 3): } \\
\text { analytical }\end{array}$ & $2.01 \pm 0.01$ & $\begin{array}{l}0.82 \pm 0.05 \\
0.68 \pm 0.06 \\
0.63 \pm 0.04\end{array}$ & $\begin{aligned} 0.88 & \pm 0.05 \\
0.81 & \pm 0.06 \\
& -\end{aligned}$ & $\begin{array}{l}0.99 \pm 0.06 \\
0.74 \pm 0.09 \\
0.78 \pm 0.08\end{array}$ & $\begin{array}{c}1.01 \pm 0.06 \\
0.78 \pm 0.09 \\
-\end{array}$ & $\begin{array}{c}0.93 \pm 0.05 \\
0.94 \pm 0.05 \\
-\end{array}$ \\
\hline $100 \%$ Cytrel & $\begin{array}{l}\text { inhalation (position 1): } \\
\text { analytical } \\
\text { inhalation (position 2): } \\
\text { analytical } \\
\text { inhalation (position } 3 \text { ): } \\
\text { analytical }\end{array}$ & $5.54 \pm 0.06$ & $\begin{array}{l}0.92 \pm 0.20 \\
0.81 \pm 0.15 \\
0.79 \pm 0.18\end{array}$ & $\begin{array}{c}1.01 \pm 0.20 \\
0.96 \pm 0.15 \\
-\end{array}$ & - & - & $\begin{array}{l}0.99 \pm 0.06 \\
0.91 \pm 0.06\end{array}$ \\
\hline
\end{tabular}

- Particulate matter, water and nicotine free.

* PMWNF total Is the sum of the PMWNF on the pad and that deposited in the machine.

Table 11. Effect of smoke concentration on inhalation machine actual smoke dellvery.

\begin{tabular}{|c|c|c|c|c|c|}
\hline Sample & Smoking machine & $\begin{array}{c}\text { Smoke } \\
\text { concentration } \\
(\%(v / v))\end{array}$ & $\begin{array}{l}\text { PMWNF* } \\
(\mu g / p u f f)\end{array}$ & $\begin{array}{l}\text { Nicotine } \\
\text { ( } \mu g / p u f f) \\
\end{array}$ & $\begin{array}{c}\text { CO } \\
(\mu g / p u f f) \\
\end{array}$ \\
\hline \multirow[t]{6}{*}{$100 \%$ tobacco } & Inhalation machine (position 3 ) & 1.45 & $1507 \pm 123$ & $127 \pm 4$ & $1548 \pm 59$ \\
\hline & & 1.75 & $1330 \pm 76$ & $120 \pm 2$ & $1490 \pm 36$ \\
\hline & . & 2.00 & $1330 \pm 63$ & $124 \pm 2$ & $1500 \pm 59$ \\
\hline & & 3.00 & $1320 \pm 13$ & $123 \pm 1$ & $1470 \pm 44$ \\
\hline & Analytical machine & - & $2095 \pm 96$ & $149 \pm 9$ & $1876 \pm 206$ \\
\hline & Ratio inhalation (mean) : analytical & - & 0.65 & 0.83 & 0.80 \\
\hline $50 \%$ tobacco: & Inhalation machine (position 3) & 2.01 & $925 \pm 59$ & $64 \pm 6$ & $1644 \pm 90$ \\
\hline \multirow[t]{5}{*}{$50 \%$ Cytrel } & & 2.25 & $939 \pm 100$ & $61 \pm 5$ & $1420 \pm 36$ \\
\hline & & 3.00 & $974 \pm 72$ & $61 \pm 6$ & $1420 \pm 23$ \\
\hline & & 4.00 & $990 \pm 28$ & $71 \pm 2$ & $1365 \pm 36$ \\
\hline & Analytical machine & - & $1466 \pm 33$ & $82 \pm 5$ & $1748 \pm 80$ \\
\hline & Ratio inhalation (mean) : analytical & - & 0.65 & 0.78 & 0.84 \\
\hline
\end{tabular}

- Particulate matter, water and nicotine free. 
Table 10. Inhalation machine: diluted smoke chemistry * for $100 \%$ tobacco clgarettes at $1.45 \%(v / v)$ smoke concentration (eampling at animal tray position 3).

\begin{tabular}{|c|c|c|}
\hline Machine & $\begin{array}{c}\mathrm{HCN} \\
\text { ( } \mu \mathrm{g} / \text { puff) }\end{array}$ & $\begin{array}{c}\text { Aldehydes } \\
\text { ( } \mu \mathrm{g} / \text { puff) }\end{array}$ \\
\hline $\begin{array}{l}\text { Inhalation machine } \\
\text { (position 3) }\end{array}$ & $\begin{aligned} 27.1 \max . & =29.6 \\
\min . & =25.1\end{aligned}$ & $\begin{array}{r}220 \max .=238 \\
\min .=203\end{array}$ \\
\hline Analytical machine & $\begin{array}{r}32.8 \max .=35.1 \\
\min .=30.2\end{array}$ & $\begin{array}{r}257 \max .=260 \\
\min .=250\end{array}$ \\
\hline $\begin{array}{l}\text { Ratlo inhalation: } \\
\text { analytical }\end{array}$ & $\begin{aligned} 0.83 \max . & =0.84 \\
\min . & =0.81\end{aligned}$ & $\begin{aligned} 0.86 \max _{.}=0.91 \\
\min .=0.78\end{aligned}$ \\
\hline
\end{tabular}

- Three determinations per quoted mean result.

lated on a per puff basis, and as such compare favourably with the CO data (Table 9).

To see if smoke concentration has any effect on actual smoke delivery from the inhalation machine, two cigarette types were studied over a range of smoke concentrations, keeping within the range normally encountered in animal exposure experiments. Data for these two products [100\% tobacco over the range $1.45 \%-3.0 \%(\mathrm{v} / \mathrm{v})$ and $50 \%$ tobacco : 50\% Cytrel over the range 2.0\%-4.0\% (v/v)] are given in Table 11, data on the diluted smoke being obtained at the 1st level of animal trays. It is clear that dilution has no significant effect on smoke delivery; the data also confirm the observation in Table 8 that PMWNF actually delivered from the inhalation machine is less than the delivery of nicotine and $\mathrm{CO}$.

\section{SUMMARY}

The paper describes experiments which have been used to evaluate an inhalation smoking machine for small animals. Deliveries of undiluted and diluted smoke from this machine have been compared to reference data obtained from an analytical smoking machine. Deliveries of smoke immediately behind the smoke pump were lower than those from the analytical machine, largely due to differences in puff number (created largely by differences in paper regression between puffs) and deposition. When these factors were accounted for, deliveries from the two machines compared favourably. However, deliveries of diluted smoke, although apparently independent of dilution level, were somewhat lower than analytical deliveries. Thus the inhalation machine delivered about $65 \%$ of the particulate matter, $80 \%$ of the nicotine and $85 \%$ of the carbon monoxide delivered by the analytical machine on a per puff basis (for $100 \%$ tobacco or $50 \%$ tobacco: 50\% Cytrel). A 100\% Cytrel cigarette delivered $80 \%$ of the particulate matter and $90 \%$ of the carbon monoxide (no nicotine). After accounting for deposition, consistent deliveries of about $85 \%$ were achieved for all three constituents in all-tobacco cigarettes, while corrected deliveries for $100 \%$ Cytrel cigarettes were about $90 \%$ for both particulate matter and carbon monoxide. Deliveries of hydrogen cyanide and total volatile aldehydes in both samples were about $85 \%$ of those achieved on an analytical machine.

\section{ZUSAMMENFASSUNG}

Zum Zwedk der Beurteilung einer Inhalationsrauchmaschine für kleine Labortiere wurden Versuche durchgeführt. Die von der Maschine erzeugten Mengen an unverdïntem und verdünntem Rauch wurden mit den entsprechenden Daten einer analytischen Rauchmaschine verglichen. Die unmittelbar hinter der Rauchpumpe gemessenen Rauchmengen waren bei der Inhalationsrauchmaschine niedriger als bei der analytischen Rauchmaschine, was hauptsächlich auf Rauchniederschlag im Rohrsystem und auf Unterschiede in der Zugzahl (vor allem durch unterschiedlichen Abbrand im Zugintervall) zurückgeführt wird. Unter Berücksichtigung dieser beiden Faktoren waren die von den beiden Rauchmaschinen erzeugten Rauchmengen vergleichbar. Trotzdem lag die Ausbeute der Inhalationsrauchmaschine bei verdünntem Rauch etwas unter derjenigen der analytischen Maschine, und zwar unabhängig vom Verdünnungsgrad. So betrugen die Ausbeuten der Inhalationsrauchmaschine im Vergleich zur analytischen Rauchmaschine auf Zugbasis bei der Partikelmasse (PMWNF*) etwa 65\%, beim Nikotin $80 \%$ und beim Kohlenmonoxid 85\% (100\% Tabak oder Tabak/Cytrel ${ }^{\circledR}$ im Verhältnis 50:50). Bei einer zu 100\% aus Cytrel ${ }^{\otimes}$ bestehenden Cigarette beliefen sich diese Werte auf $80 \%$ für die Partikelmasse und auf $90 \%$ für das Kohlenmonoxid (kein Nikotin). Unter Berüdksichtigung der Rauchablagerung machten die Ausbeuten an den drei Komponenten bei zu 100\% aus Tabak bestehenden Cigaretten regelmäßig etwa $85 \%$ aus, während sich die korrigierten Ausbeuten bei Cytrel ${ }^{\oplus}$-Cigaretten $(100 \%)$ auf etwa $90 \%$ sowohl für die Partikelmasse wie für das Kohlenmonoxid beliefen. Bei beiden Proben machten die Ausbeuten der Inhalationsrauchmaschine an Blausäure $(\mathrm{HCN})$ und gesamten flüchtigen Aldehyden etwa $85 \%$ der Ausbeuten der analytischen Rauchmaschine aus.

\section{RESUME}

Cette étude décrit les expériences effectuées pour évaluer une machine à fumer servant à exposer de petits animaux à la fumée de cigarette par voie d'inhalation. Les quantités de fumée diluée et non diluée délivrées par cette machine sont comparées à des données de référence obtenues par une machine à fumer analytique. La quantité de fumée mesurée directement derrière la pompe à fumer est plus basse que celle de la machine analytique, en raison surtout de différences dans le nombre de bouffées (attribuables principalement à la vitesse de combustion plus grande entre les bouffées) et d'un dépôt de particule dans la machine. En dehors de ces deux facteurs, les rendements en fumée des deux machines sont comparables. Cependant, le rendement en fumée diluée de la machine servant à l'inhalation, bien qu'apparemment indépendant du degré de dilution, est quelque peu inférieur à celui de la machine analytique. Ainsi, par rapport d la machine analytique, et pour un nombre égal de bouffées, la machine servant à

\footnotetext{
- particulate matter, water and nicotine free
} 
l'inhalation produit environ $65 \%$ de condensat anhydre sans nicotine (PMWNF $\mathrm{CO}$ (avec du tabac $100 \%$ ou un mélange à parts égales de tabac et de Cytrel $^{8}$ ). Avec une cigarette contenant $100 \%$ de Cytrel ${ }^{3}$, les valeurs de rendement sont de $80 \%$ de condensat anhydre et de $90 \%$ de $\mathrm{CO}$ (la nicotine est absente). En tenant compte du dépôt dans la machine, des rendements réguliers d'environ $85 \%$ ont été obtenus pour ces trois constituants de la fumée pour les cigarettes faites de $100 \%$ de tabac alors que les rendements corrigés pour les cigarettes composées de $100 \%$ de Cytrel ${ }^{\circ}$ sont d'environ $90 \%$ aussi bien pour le condensat anhydre que pour le $\mathrm{CO}$. Les rendements en acide cyanhydrique et en aldehydes volatils totaux sont d'environ $85 \%$ de ceux de la machine analytique pour les deux échantillons.

\section{REFERENCES}

1. Baumgartner, H., and C. R. E. Coggins: Description of a continuous-smoking inhalation machine for exposing small animals to tobacco smoke; Beitr. Tabakforsch. Int. 10 (1980) 169.

2. Rothwell, K., and C. A. Grant (ed.): Standard methods for the analysis of tobacco smoke; Tobacco Research Council (London) Research Paper 11 (2nd edition), 1974.
3. Anonymous: Automated $\mathrm{CO}$ measurements; Filtrona Facets published by Cigarette Components Ltd., 1976.

4. Spincer, D., and B. C. Chard: The determination of formaldehyde in cigarette smoke; Beitr. Tabakforsch. 6 (1971) 74-78.

5. Schulz, W., and F. Seehofer: Ober den Einfluß von Abrauchparametern auf die Rauchausbeuten; Beitr. Tabakforsch. 7 (1973) 105-110.

Authors' addresses:

C. D. Briggs, Gallaher Limited,

Research and Development Division, Henry Street, Belfast, Nortbern Ireland, United Kingdom.

A. Schweizer, Battelle, Centre for Toxicology and Biosciences, 7, route de Drize, CH-1227 Carouge-Geneva, Switzerland.

- particulate matter, water and nicotine free 